IRSH 55 (2010), Supplement, pp. I 23-I 5 I doi:I0.1017/So020859010000520

(C) 2010 Internationaal Instituut voor Sociale Geschiedenis

\title{
Environmental Changes, the Emergence of a Fuel Market, and the Working Conditions of Salt Makers in Bengal, c. $1780-1845^{*}$
}

\author{
S A Y A K O K AN D A \\ Faculty of Economics, Keio University \\ E-mail:kanda@a7.keio.jp
}

SummarY: During the late eighteenth and early nineteenth centuries, the British East India Company monopolized salt production in Bengal, and the British sought a new market for English salt in India. As previous studies have emphasized, external political and economic forces devastated indigenous industry and its workers. However, working conditions were influenced more by the natural environments of the salt-producing localities, particularly the availability of fuel, which was indispensable to the process of manufacture. The industry had always benefitted from abundant grass and straw for use as fuel. However, as grasslands were lost due both to constant river encroachment and to land clearance for cultivation, straw prices increased with the emergence of a regional market for biomass fuels, so that increasing difficulties in procuring fuel gradually made the salt industry costly. That state of affairs was accelerated by the advance of economic activity in general and a shortage of coal in particular. The changes made workers much more dependent on the fuel market.

\section{INDIGENOUS INDUSTRY IN THE AGE OF EXPANSION OF GLOBAL TRADE}

In Indian history, the late eighteenth to the early nineteenth century was a period when the British East India Company [hereafter, the Company] gradually consolidated its rule over India by securing stable sources of revenue. Simultaneously, world trade expanded under the free trade system and the internal Indian market became increasingly connected to the world market.

\footnotetext{
* Research for this article was supported by the Japan Society for the Promotion of Science, Grant-in-Aid for Scientific Research (B), I 8330074, 2006-2008. An earlier version of this article was read at the I 5 th World Economic History Congress, Utrecht, 6 August 2009. I would like to thank Professors Kaoru Sugihara, Kōhei Wakimura, Haruka Yanagisawa, Peter Robb, and Tirthankar Roy for their comments.
} 
The growth of the export trade in opium and cotton for the Chinese market and the rapid expansion of the Company's territories involved an increase in production of cash crops as well as large-scale movements of troops, civil servants, commodities, and bullion. In eastern India the period saw the growth of internal trade as a result of a series of institutional reforms of the Company. The Company's directors tried to establish control over markets by making them "public property", what Sudipta Sen calls "a permanent settlement of marketplaces", ${ }^{\text {, which }}$ deprived zamindars [landholders] and other landed and commercial interests of privileges and authority over them. The Company's interference in internal trade not only made it easier for it to obtain direct access to production sites, but also, as Rajat Datta argues, led to a proliferation of private marketplaces and enabled indigenous merchants "to expand their direct control over the internal market". ${ }^{2}$

The buoyancy of the economy created a new demand for safer, speedier, and larger means of transport, which led, for example, to Britain and north India's becoming connected by regular steamship routes via $\mathrm{Cal}$ cutta in the I 830 s. Furthermore, the introduction of steamships generated a demand for a new commodity - coal. The development of the coal industry was unable to keep up with the pace of demand, and the Company started looking eagerly for alternative fuels. The consequence was the emergence of a wider fuel market in Eastern India. Fuel-consuming indigenous industries were greatly affected by this new development in the early nineteenth century.

This essay explores the working conditions of salt makers, known as malangis, ${ }^{3}$ in Bengal during the period of rapid economic and political change which occurred in the late eighteenth and early nineteenth centuries. The production of salt in Bengal and Bihar was monopolized by the Company in 1772 , and, through a major institutional change in 1836 , the monopoly lasted until I 863 , when it was finally abolished. Then, Bengal salt was driven from the market and Cheshire salt imported from Liverpool became almost the sole variety of salt consumed in eastern India.

The dislocation of indigenous industries has been explained in the context of colonial rule and expanding global trade. It has been argued that the Company's monopoly, with its discriminatory practices, gradually devoured the established salt industry by depriving it of its competitiveness. Cheshire salt and Liverpool shipping interests applied political

I. Sudipta Sen, Empire of Free Trade: The East India Company and the Making of the Colonial Marketplace (Philadelphia, PA, I998), chs 4-5.

2. Rajat Datta, Society, Economy and the Market: Commercialization in Rural Bengal, c. $1760-I 800$ (Delhi, 2000), pp. 200-206.

3. The salt manufacturers were commonly called malangis, but the term included several occupations without distinction, including boilers and coolies. 
pressure which helped set the stage for the influx of Cheshire salt into eastern India. ${ }^{4}$ Inherent in that and other established views is the assumption that the economic transition should be examined within the framework of dichotomies: free trade and monopoly; Britain and India; and Bengal salt and Cheshire salt. Such dichotomous approaches see the Company and British capital as the prime forces behind the globalization of trade and the transformation of the indigenous economy. In turn it is assumed that the indigenous society was a silent witness to the changes.

The working conditions of the malangis under the Company were also discussed in terms of such dichotomous approaches. The select committee appointed in I 836 to examine the salt monopoly in India was especially instructed to examine the working conditions of malangis. Those who opposed the monopoly, including British salt importers, insisted that the malangis were "the most wretched human beings" and their conditions were "in the state of slavery", because the Company relied upon a system of coerced labour. 5 The Company, which was in a position to preserve the monopoly, contradicted their claims, stressing that the malangis were better off than cultivators in the area, since salt production promised them an extra income in addition to what they cultivated on their own lands, and said that laws and regulations protected them from extortion.

Both views, however, failed to notice the changes in their conditions over the period under consideration. External political and economic forces were not the only influence on the fate of the salt industry and its workers. The present article attaches much importance to the environmental factors that influenced the performance of the industry and the conditions of its workers. The industry was located in the vast area along the Bay of Bengal, where raw materials, including seawater and fuel, were abundant. Thus, the industry was fortunate in having available such local environments, producing a large quantity of salt and profits both for the Company and the malangis. However, at the same time, the surroundings could make them very vulnerable. The salt industry and its workers were prone to tidal floods, cyclones, and tigers, to say nothing of constant changes in the river courses themselves. At least seven floods in the Ganges catchment and two in the Brahmaputra catchment areas were recorded during the period under consideration, ${ }^{6}$ and salt production was hit severely by them, as was the case in 1787 .

4. For instance, Indrajit Ray, "Imperial Policy and the Decline of the Bengal Salt Industry under Colonial Rule: An Episode in the 'De-Industrialisation' Process”, Indian Economic and Social History Review, 38 (2001), pp. I8 I-205.

5. For these contradicting observations (between D.C. Aylwin, a member of Aylwin \& Co., and F.J. Halliday, Secretary to the Government of India, Home Department), see Appendix F, no. 3, British Parliamentary Papers [hereafter, BPP], XXVI, I 856.

6. Thomas Hofer and Bruno Messerli, Floods in Bangladesh: History, Dynamics and Rethinking the Role of the Himalayas (Tokyo [etc.], 2006), pp. 63-69. 
The availability of fuel was influenced by such environmental factors also, and began to be affected by the growth in economic activity during the same period. Since the supply of coal was insufficient to meet increasing demand, fuel consumers began to exploit local firewood as an alternative. The rise in general fuel prices had an adverse effect on the salt industry and began to reduce the profits of its workers. The Company's policy also had to deal with such changing local ecological and economic conditions in order to stabilize salt production. Thus, to assess the working conditions of the malangis and changes in them over the years, we need to examine those working conditions in relation to much wider ecological, economic, and social changes.

\section{THE MALANGIS UNDER THE COMPANY'S SALT MONOPOLY}

\section{The Company's salt policies}

Under increasing pressure to secure revenue to finance extensive military campaigns and to pay salaries for its servants, the Company began to take measures to maximize revenues from salt. By a series of reforms in production and marketing during the I780s, the Company successfully established a stable system of monopoly, which was characterized by the high price of salt maintained by the Company's strict control of its supply. Salt then became the second largest revenue source for the Company, playing a crucial role in consolidating Company rule.

In 1780 , the Company started to take direct control of production and prohibited the private production of salt and other saline substances such as byproducts of saltpetre manufacture and the ashes of certain plants. ${ }^{7}$ The private importing of salt was banned too, both by land and sea, although it had been one of the most important sectors of Bengal's import trade. In the same year, the salt agency system was instituted under the Board of Revenue. ${ }^{8}$ All the salt aurangs or manufacturing divisions along the Bay of Bengal were integrated into six agencies at Hijili, Tamluk, the Twenty-Four Parganas, Raymangal, Bhulua, and Chittagong. ${ }^{9}$ Salt agents were appointed by the Board of Revenue to manage their respective agencies.

7. India Office Records, British Library [hereafter, IOR], Bengal Board of Revenue (Miscellaneous) Proceedings, Salt [hereafter, BRP-Salt], P/I0I/56, I 3.I0.I829, no. I; West Bengal State Archives, Letter from the Superintendent of Western Salt Chokies, Proceedings of Bengal Board of Trade, Salt [hereafter, BT-Salt], CIII, I.8.1815. The production of certain kinds of industrial salt unfit for human consumption in Bihar, known collectively as khari nun, was the only exception. BRP-Salt, P/IOI/56, I3.10.1829, no. I; Letter from the Superintendent of Western Salt Chokies, BT-Salt, CIII, r.8.18 is.

8. The Board of Trade took over the salt business in 1793 until the establishment of the Board of Customs, Salt and Opium in I8r 9 .

9. In the Sundarbans area, there were two major rearrangements of the agencies. In I80I, the Raymangal agency was abolished due to heavy costs. In 18 19, the eastern half of the Twenty-Four 
The agents would contract with the malangis and pay advances to them as well as supervise the entire process of salt production, the storage of salt in the Company's warehouses, and its delivery to merchants. Agents were also required to be on the lookout for illegal production and smuggling. A chain of native officers at different stages in the production process enabled a salt agent to manage the entire scope of commercial activities within his region. Under that system, the Company exercised direct control over production, abolishing customary intermediate interests between the Company and malangis, such as zamindars, European and native revenue farmers, and merchants. ${ }^{10}$

To centralize sale and distribution and allow it to raise prices further, in I788 the Company introduced sales by public auction, abandoning the practice of making sales at a fixed price. Under the auction system, the annual quantity of salt supplied to the market was fixed at about 3,000,000 maunds, ${ }^{\text {I }}$ and all salt, domestic and foreign, was sold in Calcutta at auctions held several times a year. The new sale system encouraged competition among salt purchasers. ${ }^{\mathrm{I}}$ In January, the annual quantity of supply and the production quota of each agency were determined on the basis of production estimates reported by the Company's agents, salt prices in Calcutta and major commercial centres, and the reserves of salt in the Company's warehouses. The reserves included foreign salt ${ }^{13}$ and purchasers' salt that had not yet been shipped from the warehouses.

\section{Bengal method of production and location of salt industry}

In many parts of coastal India, where seawater was readily available, solar-evaporated salt was widely produced. In contrast, Bengal salt was a boiled variety, known as panga. The Bengal method followed a boiling process because Bengal's extreme humidity made it difficult to crystallize

Parganas agency was separated to form the independent Jessore agency. The Joynagar agency operated experimentally for two seasons in 1793-1794 and I794-1795.

I0. For details see Sayako Miki, "Merchants, Markets, and the Monopoly of the East India Company: The Salt Trade in Bengal under Colonial Control" (unpublished Ph.D. thesis, University of London, 2005), ch. I.

I I. One maund is the equivalent of about 37.3 kilograms.

I2. Salt merchants also played a significant role in maintaining high salt prices, and consequently the monopoly system itself. They purchased salt at public sales and pushed up prices on the market. For details see Miki, "Merchants, Markets, and the Monopoly", chs I, 3 .

I3. The import of salt was not included in the trade statistics, because salt was "a source of revenue, and not of commerce"; IOR, Report on the External and Internal Commerce of Bengal in the Year I8I8-I8I9, Bengal Commercial Records, P/I74/30, I8I8-1819. However, foreign salt, particularly from Coromandel and Orissa, played a crucial role in tackling smuggling and illicit production in the monopoly system, accounting for roughly one-quarter share of the total supply of salt in Bengal and Bihar. For details see Miki, "Merchants, Markets, and the Monopoly", chs I-2. 


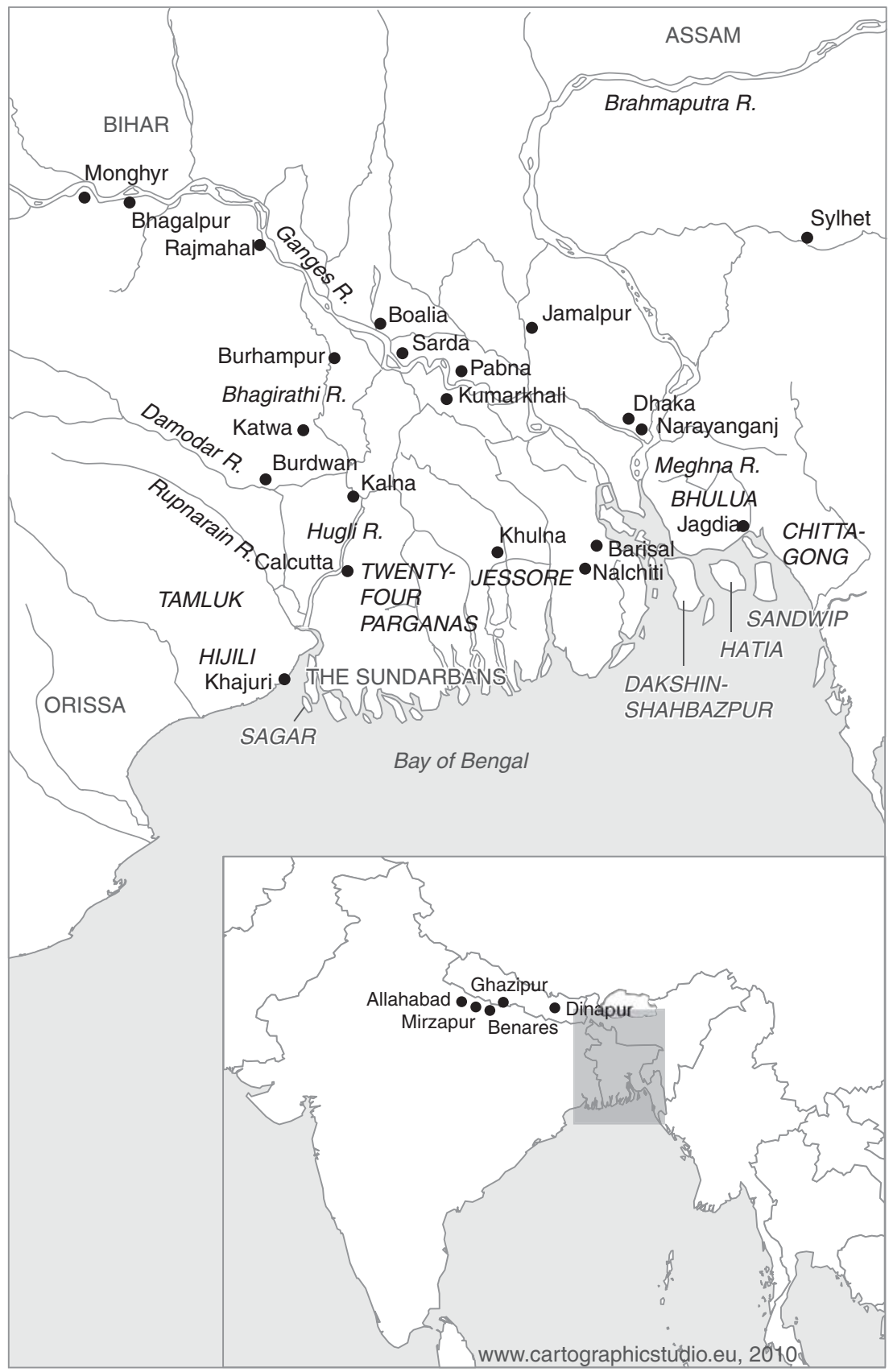

Figure I. Map of eastern India in the early nineteenth century. 
brine by solar power alone and the readily available fuel made panga production possible there. Fuel materials of low calorific value such as grass and paddy straw were generally used to boil brine, and even brushwood was occasionally used when no alternative was available. By boiling brine for long hours in small earthenware pots at low temperatures, finer and whiter salt was produced. Bengal salt was popular among consumers in Bengal, and thus fetched higher prices in the region's market. ${ }^{I 4}$ Solar salt, which was imported mainly from the Coast of Coromandel, was unpopular because of its muddy appearance and inherent impurity. Such consumer preference had kept the price of solar salt low in most of Bengal, and it was supplied mostly to poorer and remote areas where Bengal salt was not generally available. ${ }^{\text {Is }}$

The manufacturing season in Bengal began in October or November and ended in June or July before the seasonal rains began. Well before manufacturing began, malangis prepared by clearing salt grounds and making saltpans. From the saltpans that had been filled with salt water, they collected brine and then boiled it to make the salt. Malangis were responsible for producing a fixed amount of salt according to their respective taidads or contracted quantities and for delivering the product to the salt agent as it was produced. They settled their accounts with the agent at the end of the season. Since the advances given to malangis included all the costs incurred in the manufacturing process, it was their responsibility to procure sufficient fuel and pots for their season's work.

All the agencies followed similar production methods and time schedules, but geographical and environmental differences among them influenced their performance. The Hijili and Chittagong agencies, and to a lesser extent the Tamluk agency, had more suitable environments for salt production. Those agencies were able to produce salt of higher quality, because they were located far enough from the mouths of great rivers for the process of collecting brine to be less affected by fresh water or by natural changes in water flow, which caused soil erosion and devastated the land areas where fuel could be collected, and ruined the saltpans themselves.

Many production sites of the Twenty-Four Parganas, Raymangal, Joynagar, and Jessore agencies were situated within the Sundarbans jungle.

I4. Until the mid-I 820 s the price of Bengal salt was generally about 100 rupees per 100 maunds higher than the average price of solar salt. For instance, the average price of Coromandel solar salt for 8 public sales from May to December i 825 was 317.08 rupees per 100 maunds, while that of Hijili salt was 419.5 rupees (calculated from Calcutta Exchange Price Current, 2, nos $332,337,34 \mathrm{I}, 345,350,355,359$, and 363 (I 825$)$ ).

I 5. For the difference in production method and taste, see Sayako Kanda, "Taste, Merchants and the Expansion of the Global Trade: Competition and Changes in the Salt Market in Eastern India, c.I 820-1860", paper presented at Session H-5, I sth World Economic History Congress, Utrecht, 5 August 2009. 


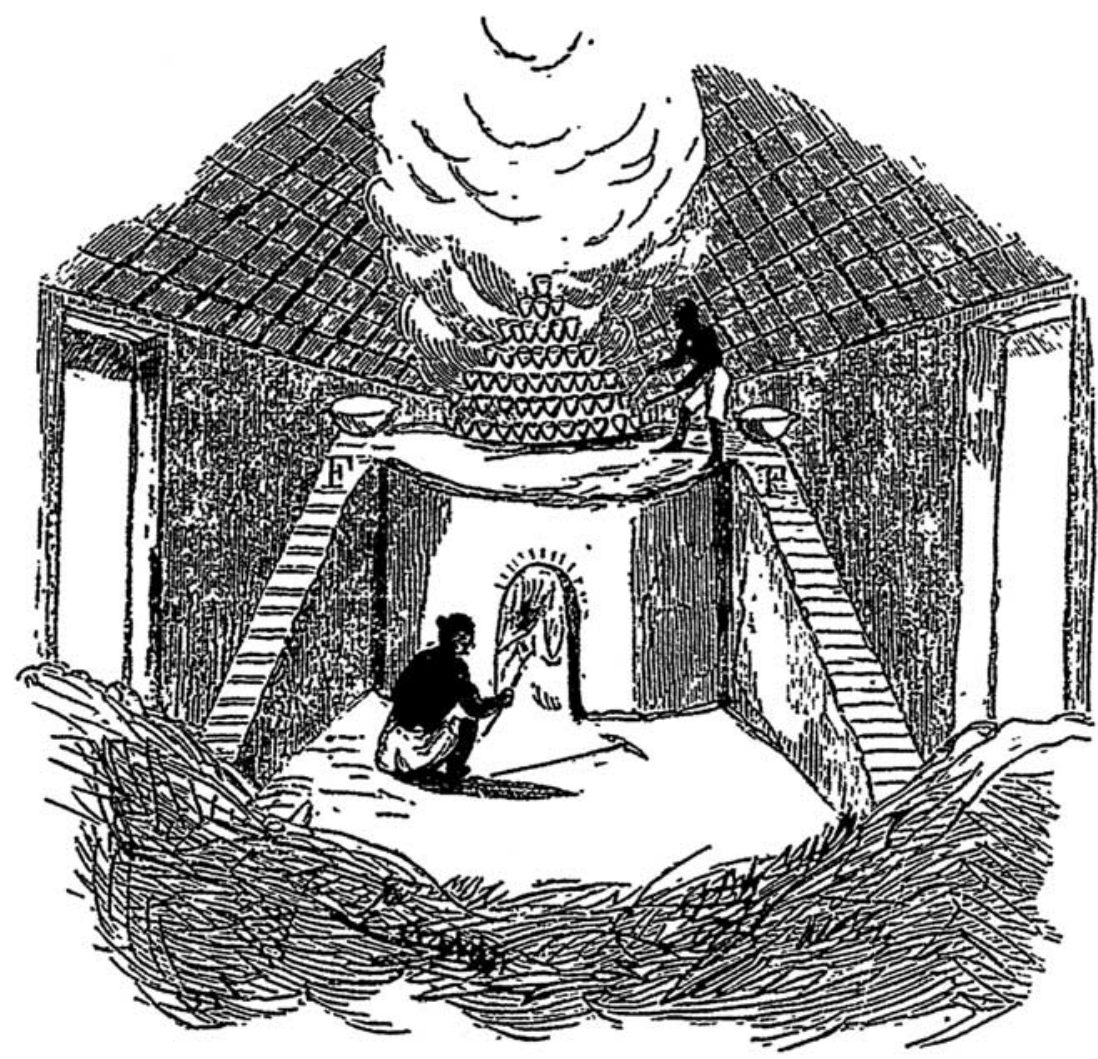

Figure 2. The interior of a boiling house in Tamluk, with two malangis boiling brine with grass or paddy straw.

Source: Notes on the Manufacture of Salt in the Tamluk Agency, by H.C. Hamilton, Salt Agent, Dated September 23, I852, Appendix B, BPP, vol. 26, I856.

Salt production for those agencies was environmentally challenging, since they had to overcome constant permeation of fresh water from the Ganges and its branches, as well as frequent tidal floods. Salt workers themselves also had to cope with diseases and wild animals. For instance, it was reported that the Raymangal agency lost 439 salt workers during the manufacturing season of $1788-1789$ alone: 309 were killed by tigers, 3 killed by gavials - alligator-like creatures - IIs died of disease, I I drowned, and I fell out of a tree. ${ }^{16}$ The malangis of those agencies frequently

I6. BRP-Salt, P/88/72, I 2.I I.I789. The reptiles that killed three people were called "alligators" in this report, but since the Ganges was not a natural habitat of the alligator, it is highly likely that they were in fact gavials. 
petitioned the salt agents to take safety measures against tigers, and although attempts were made to set traps, and the huts were surrounded with fences of gram branches, and the men even used the noise of wooden sticks to keep the tigers away, ${ }^{17}$ such measures proved ineffective.

Moreover, in contrast to the state of affairs in other agencies, the saltpans were in the woods some way away from inhabited areas, so that the malangis, together with the coolies and woodcutters who cleared the woods for making the salt grounds, had to be sent to the manufacturing places along rivers which were difficult to navigate. In addition, supplies for these people and the boiling pots also had to be floated to the places of manufacture in a fleet of small boats of 1,500 to 2,000 maunds. ${ }^{18}$

The location of the Bhulua agency too was environmentally disadvantageous, since the production sites were scattered around the mouth of the mighty Meghna, as well as on several islands: Dakshin Shahbazpur, Sandwip, and Hatia. Salt production was often affected also by strong tides and the constant encroachment of rivers, which destroyed saltpans and grasslands.

\section{The control of production and the welfare of the malangis}

The total number of salt makers employed by the Company was estimated to be 60,000 between 1780 and 1836, assuming each malangi would produce 50 maunds of salt and that during that period the annual production level was set at $3,000,000$ maunds. ${ }^{19}$ According to a police estimate in I823, the population of Bengal and Bihar was 35,593,307, of which 4,757,685 resided in the coastal districts of Midnapur, the TwentyFour Parganas, Jessore, and Chittagong. ${ }^{20}$ The malangis made up about I.3 per cent of the total population of coastal districts. The population of the malangis in itself was not significant, but if we include their dependents and related workers such as coolies, woodcutters, potters, and boatmen, the number of people dependent on the salt industry was much greater.

The salt agents were responsible for producing the authorized annual quota, an important task because success or failure in production would determine the Company's salt revenues. Weather conditions, such as excessive rainfall, storms, and unusually high tides during the preparing and manufacturing seasons, often caused production failures. For example, the failure in I794-I795 in Tamluk was caused by excessive rain and uncommonly high spring tides in late October that overflowed the

17. Ibid.

I8. BRP-Salt, P/88/74, I7.I I.I790.

I9. BRP-Salt, P/IOI/I I, I 3.I.I 826, no. I 2.

20. This estimate included Bengal, Bihar, and foreign settlements (BRP-Salt, P/roI/44, II.II.I 828 , no. I). 
salt grounds. ${ }^{21}$ The severe storm that hit Tamluk in May I 833 not only destroyed salt but also made food collection difficult for the next season. ${ }^{22}$ Constructed at the discretion of the agents, secure embankments around saltpans and warehouses were built to prevent damage from floods and high tides - although not always successfully so, in spite of the agents and their assistants making regular trips to inspect such embankments. ${ }^{23}$

The salt agents were also expected to take immediate relief action whenever the malangis themselves suffered from natural disasters, which of course hampered the level of production. For instance, when floods damaged a vast area of the Hijili Agency in July I824, the salt agent immediately supplied the malangis with rice, beans, and chilli peppers to help the people recover and get back to work. ${ }^{24}$ On another occasion, to mitigate the difficulties of the malangis, the salt agent of Hijili asked the Company for permission to produce 100,000 maunds of salt in addition to the authorized quantity of 800,000 maunds. ${ }^{25}$

Workers were also exposed to various diseases. The failure in $1798-1799$ in Bhulua was due to unseasonable rain from January to May that helped spread contagious diseases among the malangis. ${ }^{26}$ According to C. Herd, who toured the Tamluk agency after the severe storm in May I833, many of the malangis had fallen victim to cholera morbus and an unspecified fever. ${ }^{27}$ Although no malaria was reported from the salt districts during that period, ${ }^{28}$ people were prone to "apoplexy, paralysis, inflammatory fever, and sudden attacks of cholera", due to the unhealthy circumstances of a tropical climate. ${ }^{29}$ The first priority of the salt agents was to make sure that victims of such natural calamities recovered as soon as possible so that they could continue to work through the rest of the current and following seasons.

The timing of advance payments to the malangis also played a crucial role in the success or failure of production. According to Richard Goodlad, the salt agent at the Twenty-Four Parganas, "the success of the salt manufacture depends in a great measure on the funds which are

21. IOR, Bengal Revenue Consultations (Salt, Opium and c.) [hereafter, BRC-Salt], P/98/32, I 8.7.1796, no. I.

22. BRP-Salt, $\mathrm{P} / \mathrm{I0} / 84$, 7.1.1 834 , no. I.

23. BRP-Salt, $\mathrm{P} / \mathrm{I} / \mathrm{I} / 56$, 6.1 1.1829, no. 8.

24. BRP-Salt, P/I00/70, I7.8.1824, nos I I-I 2.

25. BRC-Salt, $\mathrm{P} / \mathrm{100} / 3,26.4 .1816$, nos 6-8.

26. BRC-Salt, $\mathrm{P} / 98 / 38,2$ I. 8.1800 , no. I.

27. BRP-Salt, P/ro4/84, 7.I.I 834 , no. I. According to his estimates, about one-third to one-half of the coolies had died or left the area.

28. According to Ira Klein, "the deadly form of malaria which became known ultimately as Burdwan fever [...] originated in Jessore, in the late I 830 os"; Ira Klein, "Malaria and Mortality in Bengal, I840-192 I", Indian Economic and Social History Review, 9 (1972), pp. I32-160, I38. 29. Khondker Ifthkhar Iqbal, "Ecology, Economy and Society in the Eastern Bengal Delta, c.I840-1943" (unpublished Ph.D. thesis, University of Cambridge, 2005), p. 68. 
necessary for carrying it on, being forthcoming at the exact periods at which they are wanted". ${ }^{\circ}$ In 1793 , when the remittance of the advance money was delayed from the Company's treasury because of a general shortage of silver rupees, he used his private account to borrow money from Gopal Das Hari Kissen Das, a large Benares banking concern, and distributed those funds to the malangis without delay. ${ }^{3 \mathrm{I}}$

In the Hijili agency, the first advance was made in the middle of November at the office of each manufacturing division to enable the malangis to prepare their lands for manufacture and to give necessary advances to their coolies and potters. ${ }^{32}$ The agent and his assistants visited all the manufacturing divisions to make the second advance in February. The third advance was made in April. After concluding the season in early June, the malangis came to the division office to settle their accounts. There were also intermediate advances, known as bowlath, to meet the occasional exigencies of the malangis for the supply of fuel. Such intermediate advances enabled the malangis to buy straw for fuel when it was plentiful and cheap. In Tamluk, the malangis were in the habit of using such intermediate advances to go to the banks and sandbanks of the Rupnarayan to obtain various types of reed during the cold season when rivers were easily navigable. ${ }^{33}$

In the Twenty-Four Parganas, where salt was manufactured in the jungle, an extra concession for malangis seems to have been necessary. At the end of July, the early advance was made soon after the malangis returned from the woods, when "they are greatly distressed, the manufacture of salt is at an end and their lands at that season are entirely unproductive" ${ }^{34}$ In early October, the second advance was given to the malangis when they were dispatched to the woods to prepare salt grounds and cut sufficient fuel for the entire boiling season. When they returned from the woods after about forty days to look after their cultivated lands, the December advance was made to enable them to "settle their revenue accounts and quit the cultivated country" by early January to manufacture salt. Besides, whenever necessary, the agents helped poorer malangis with small, extra advances. The time schedule of payment was determined at the discretion of the salt agents. The diversity of manufacturing locations, the availability of fuel and coolies, and the relationships between malangis and landholders helped to determine the timing of payment. ${ }^{35}$

The salt agents also had to make sure that malangis spent the advances exclusively on the manufacture of salt and that none of them pocketed a portion of it. It was a well-known saying that the salt agencies were "a

30. BRC-Salt, P/98/25, 26.7.I 793, no. 2 .

3I. BRC-Salt, P/98/25, I I.I I.I793, no. 4 .

32. BRP-Salt, P/IоI/56, 6.I I.I 829, nos 7-8.

33. BRP-Salt, $\mathrm{P} / \mathrm{IO}_{4} / 84$, 7.1.1834, no. I7.

34. BRC-Salt, P/98/25, 26.7.1793, no. 2.

35. BRP-Salt, P/ıог/56, 6. I i.i 829, nos 9-i 2. 
pagoda tree". The officers of the salt agencies were not only relatively well paid but also well placed to take bribes from malangis. ${ }^{36}$ To avoid any sense of impropriety, some malangis even asked for paddy straw, baskets, and earthenware pots instead of cash. ${ }^{37}$ While the Company protected them from extortion by regulation (Clause 2, Section II, Regulation X of I 8 I9), the salt agents tried to hand small sums at a time to the malangis in person without depending on agency officers. Since the amount of the first advance was larger than other instalments, they took particular care in the handling of that payment.

The availability of fuel influenced the performance of the salt agencies. It was necessary for the malangis to collect enough fuel for the boiling season, using the advance money paid by the Company. In and around the salt producing districts, "the lands bearing fuel the produce of which has from time immemorial been appropriated to the boiling of salt, have ever been considered as reserved to the use of the manufacture", and the malangis were allowed to use the grass without paying for it. ${ }^{38}$ In some areas, "the ryots [raiyats] when they reap the harvest, just cut off the ears and leave the straw which the molunghees [malangis] collect for fuel, and the ryots [raiyats] are paid at the rate of 4 annas per begah [bighas] though the straw is worth much more". ${ }^{39}$ When the malangis failed to gather enough fuel through such customary means, they had to purchase straw in the market or obtain other kinds of grass from distant places at their own cost.

The salt agents occasionally helped the malangis procure fuels in order to prevent delay to production. For example, when the grasslands in Hijili were flooded because of the collapse of dykes in 1788 , the salt agent asked permission to cut brushwood in the neighbouring Tamluk jungle to make up the deficiency. ${ }^{\circ}$ In Twenty-Four Parganas the proprietors of grasslands began to claim their right to receive annual rent from the salt agent, a practice that interfered with the customary right of the malangis to obtain grass there. In such cases, the agent was forced to pay the rent to facilitate the smooth running of the malangis' business. ${ }^{4 \mathrm{I}}$

36. Girishchandra Bose, Sekaler Darogar Kahini [The Memoirs of a Chief Constable] (Calcutta, I888, reprinted 1983), pp. 165-166. Bose was the kerani [head writer] of the Tamluk agency before he became the police daroga [superintendent] in 1853 . He recollected the earlier prosperous days of the salt agencies, when every servant had some share, and when malangis gathered at the agency headquarters to receive the season's advances. He also pointed out that the salt agent usually connived at this abuse.

37. BRP-Salt, P/I0I/56, 6.1 I.1829, no. 8 .

38. BRC-Salt, $\mathrm{P} / 98 / 25$, 9.12.1793, no. I.

39. Ibid. A raiyat is generally translated as a peasant. One rupee equals sixteen annas, and one bigha is about one-third of an acre.

40. BRP-Salt, $\mathrm{P} / 88 / 72$, 3.2.1789; 25.2.1789; 10.3.1789.

4I. BRC-Salt, P/98/25, 9.I2.I793, nos I-2. The lease of 4,000 bighas of grasslands in Calcutta

Pargana alone cost the agency about 2,600 rupees annually. 


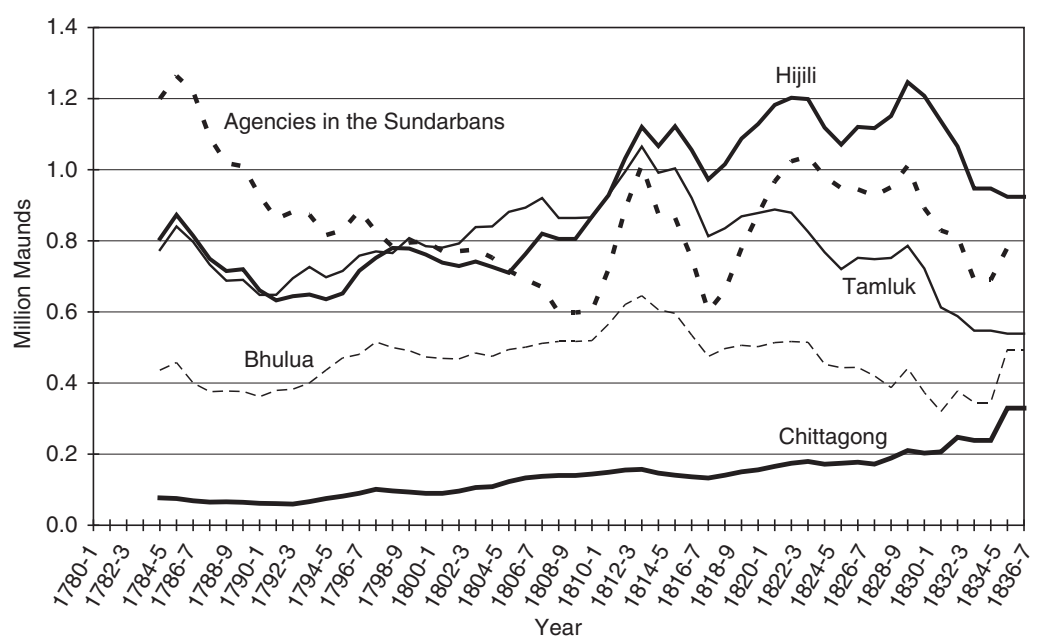

Figure 3. Salt production of Bengal agencies, $1780-1837$ (4-year moving average).

Note: Production for the years I 830-1831 and I $832-1833$ has been estimated. Agencies in the Sundarbans include the Twenty-Four Parganas, Raymangal, Joynagar, and Jessore. ${ }^{43}$

\section{Production and cost}

The Company set a production ceiling of 3,000,000 maunds and increased it to $4,000,000$ maunds in the early I 820 s. Production decreased from the late I 820 , mainly due to unfavourable weather conditions. The I824, I827, and I83 I seasons were especially bad in Bengal, and annual production then dropped to 2,500,000 maunds. The total annual supply of salt including foreign salt was about 3,500,000 maunds in the I780s and I790s, 4,500,000 maunds in the latter part of the first decade of the nineteenth century, and reached a level as high as 5,000,000 maunds in the mid-1820s. However, consistent with the decline in salt production in Bengal, that figure began to decrease in the late 1820 s and fell to $3,800,000$ maunds in $1835 .{ }^{42}$ The deficiency in Bengal salt was made good by Coromandel and Orissa salt.

As Figure 3 shows, environmental differences were reflected in the levels of production and productivity of the salt agencies. Hijili was the

42. BRP-Salt, P/I0I/52, I0.7.I 829, no. I6; P/I02/9, 27.I.I832, no. 20; P/I05/35, 28.2.1837, no. I 2. 43. BRP-Salt, P/89/2, 5.I 2.I792; P/I00/I 3, 26.I2.I 8 I7, no. 4; P/I00/23, I6.I 2.I 8 I 8 , no. I; P/I00/ 28, 24.9.18I9, no. 2; P/I00/36, 20.10.1820, no. 4; P/I00/43, I4.9.I821, no. 3A; P/I00/52, 24.9.I 822, no. 8A; P/I00/6I, 30.9.I823, no. II; P/I00/72, I9.II.I824, no. 29; P/I0I/I2, 28.2.I 826, no. 5; P/IOI/3 I, 4.I2.I827, no. 7; P/IOI/42, I6.9.I828; no. 68; P/IO2/7, 23.I 2.I83 I, no. 3; P/I02/28, 27.I 2.I832, no. 27; BRC-Salt, P/98/26, 28.7.1794, no. 5; P/98/27, 8.5.I795, no. 4; P/98/27, 20.7.I795, no. 2; P/98/32, I8.7.1796, app. no. I; P/98/35, 25.7.1799, no. 8; P/98/43, 5.8.1802, no. 3; P/99/I6, 30.1.1806, no. 2; P/99/26, I .9.1807, no. 2; P/99/30, г 2.8.1808, no. 3; P/99/34, 25.8.1809, no. 2; P/99/39, 29.10.I 8 I0, no. 3; BT-Salt, General Statement of the Produce etc., vol. 75, 4.8.I8 I 2; vol. 85-2, I7.8.18 I3; vol. 95, 23.8.I8 I4; vol. I I3, I6.8.I8I6. 
Table I. Average sale prices at public auction, I823-I 824 to $1832-1833$.

\begin{tabular}{lccc}
\hline Agency & Price (per 100 maunds) & Agency & Price (per 100 maunds) \\
\hline Hijili & 387.9 & Jessore & 408.46 \\
Tamluk & 406.64 & Bhulua & 376.17 \\
Twenty-Four Parganas & 419.15 & Chittagong & 388.94 \\
\hline
\end{tabular}

Source: BRP-Salt, P/I05/2I, 2.2.1836, no. IIH.

largest producer and its production level increased more quickly than that of other agencies, particularly in the I 820 . Hijili's production quota was set at 800,000 maunds initially but was later increased to I, 100,000 maunds. Chittagong too showed a steady increase in the same period. The TwentyFour Parganas agency produced as much salt as Hijili and Tamluk in the early years, but its production fluctuated dramatically because of the manufacturing challenges in the Sundarbans. The Raymangal and Joynagar agencies were closed due to heavy expenses. Even so, the Company expanded salt production in the Sundarbans. In I8 19 , the eastern half of the Twenty-Four Parganas agency was separated, creating the Jessore agency; this measure was taken because the salt produced in those agencies fetched much higher prices on the market in spite of its inferior quality.

As Table I demonstrates, Twenty-Four Parganas and Jessore salt was sold at a higher rate than superior Hijili and Chittagong salt. Consumers appreciated the salt made from the sacred Ganges water, which raised the ritual value of these varieties of salt. ${ }^{44} \mathrm{~A}$ general decline in the salt production from Tamluk and Bhulua, shown in Figure 3, was largely due to fuel problems.

As Figure 4 shows, the cost of production in the agencies situated in the Ganges Delta was high from the beginning, and increased further in the I 820 s, while the cost of Hijili and Chittagong was relatively stable throughout the period. Production costs in Tamluk remained as low as in Hijili, but began to increase from the mid-i 8 ios to almost the same level as that of other costly agencies.

The costs incurred in the production of Bengal salt can be classified into two groups: production costs and administrative costs, which were related chiefly to management. The administrative costs included commission paid to the superintendents of the salt chokis or toll stations, commission paid to agents and their assistants, and the proportions taken by the salt office and choki establishment. Figure s compares the average costs of production for I8I5-I8I6 and I8I6-I8I7 with that for I825-I826 and I $826-$ I 827 . The administrative costs were relatively unchanged between

44. Appendix F, no. 2, BPP, vol. 26, i 856. 


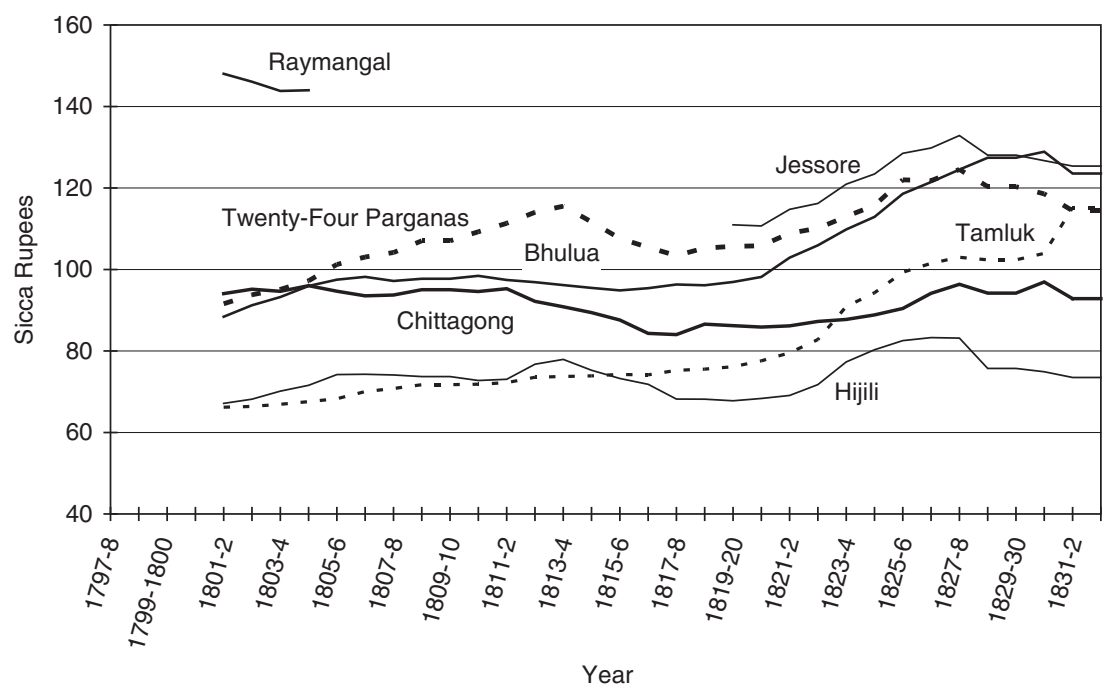

Figure 4. Costs and charges for producing 100 maunds of salt ( 5 -year moving average).$^{45}$

the two periods. ${ }^{46}$ In the Twenty-Four Parganas and Tamluk, the increase in administrative costs was due to cash rewards granted to the merchants, an idea introduced in I 824 to encourage them to deliver their salt to market. ${ }^{47}$

Because administrative costs remained stable, it is likely that the cause of increasing costs lay in production. The main categories of production

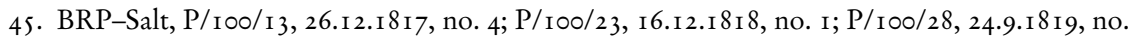

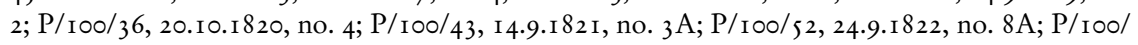
6I, 30.9.1823, no. II; P/I00/72, I9.II.I824, no. 29; P/IOI/I2, 28.2.1826, no. 5; P/IOI/3I, 4.I 2.I 827, no. 7; P/IOI/42, I6.9.1 828, no. 68; P/IOI/70, 2 I.I.I83 I, no. 8I; BRC-Salt, P/98/35, 25.7.I799, no. 3; P/98/43, 5.8.1802, no. 3; P/99/I6, 30.1.1806, no. 2; P/99/26, I I.9.1 807, no. 2; P/ 99/30, I 2.8.1808, no. 3; P/99/34, 25.8.1809, no. 2; P/99/39, 29.10.18 10, no .3; BT-Salt, General Statement of the Produce, etc., vol. 75, 4.8.I 8 I 2; vol. 85 -2, I7.8. I 8 I 3; vol. 95, 23.8. I 8 I 4; vol. I I 3 , I6.8. I 8 I6.

46. The proportions taken by the salt office and choki establishment remained almost unchanged at 5.19 rupees per 100 maunds of salt between I $80 \mathrm{I}-\mathrm{I} 802$ and I $828-\mathrm{I} 829$. The rate of commission to the salt agents fluctuated until the mid-i 8 Ios, because of the reward system, by which agency officers were entitled to receive rewards when they apprehended smugglers. It later decreased and eventually stabilized to an average of 7.63 rupees between I 8 I $4-18$ I 5 and I 828-I 829. The rate of commission paid to the superintendents of the salt chokis was only 2.69 rupees throughout. Calculated from the sources for Figure 5.

47. Due to their financial difficulties, the stock of merchants' salt in the Company's warehouses increased in the I820s. To solve this problem, which caused a shortage of salt in the remote markets, this new system was introduced. Although at first deemed a temporary solution, it was reintroduced in 1827 and I 830 . Thereafter the cost became the second largest item for agencies after the prime cost. For details see Miki, "Merchants, Markets, and the Monopoly", ch. 3. 


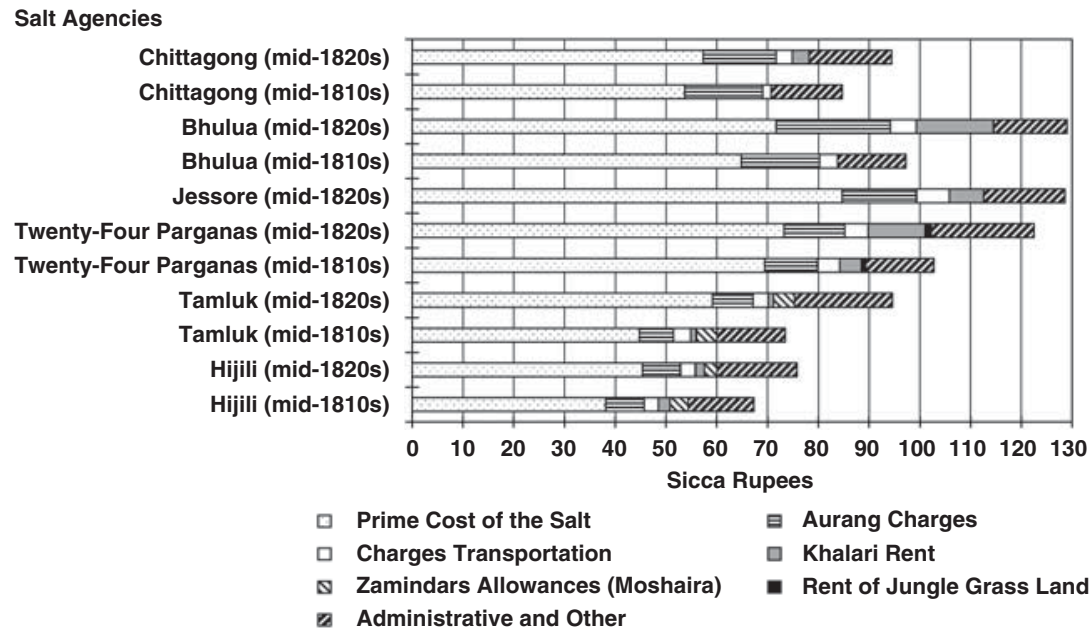

Figure 5. Average costs of production per 100 maunds of salt.

Note: The figures for the mid-1 8 Ios and the mid-1 820 s refer to the average costs for I 8 I $5-1816$ and I816-I817, and those for I $825-1826$ and $1826-1827$ respectively. ${ }^{8}$

costs were the "prime cost" of the salt, the charges of the aurang or manufacturing divisions, transport charges, the khalari rent, zamindars' allowances in Hijili and Tamluk, known as moshaira; and the rent of jungle grasslands in the Twenty-Four Parganas. The prime cost of the salt, amounting to 60 per cent of all production costs, included the total amount advanced to the malangis during a season. Aurang charges included all costs and charges related to managing production sites, such as the salaries of native officers in manufacturing and weighing establishments, expenses for building and repairing offices and warehouses, the purchase of fuel by the salt agent, gifts to industrious malangis, and any other small disbursements relating to the manufacturing divisions. ${ }^{49}$ Transport costs were related primarily to the shipment of salt from production sites to the salt wharves, where it was stored for later shipment. The khalari was the rent paid to the landowners of the saltpans.

Production costs increased for reasons which varied among agencies, except for a general increase in the prime cost. Figure 5 shows that the prime cost of the Twenty-Four Parganas, Raymangal, and Jessore agencies was higher because, as we saw earlier, those located in geographically

48. BRC-Salt, IOR P/I00/I3, I9.I2.I8I7, no. I; P/I00/23, I6.I2.I8I8, no. I; P/I0I/3I, 4.I 2.I 827 , no. 7; $\mathrm{P} / \mathrm{IOI} / 42$, I6.9.1 828 , no. 68.

49. Letter from the Agent at Hijili, BT-Salt, vol. 77-I, I4-I0.I 8 I 2. 
challenging areas generated additional expenses. Another problem in those agencies was that some malangis absconded with their advance money. ${ }^{50}$ The locations of manufacturing sites in the woods made it difficult for the salt agents to search them. In the case of the Twenty-Four Parganas, there was a wide gap in the rate of the advance money to the malangis between the distant divisions in wooded areas and those near Calcutta. The difference was so large that malangis around Calcutta deserted to wooded areas to obtain higher rates. Some of them even registered under fictitious names in distant divisions. ${ }^{5 \mathrm{I}}$ The salt agent tried to solve the problem by increasing the rate in the divisions near Calcutta to reduce the gap. The highest rate given to the malangis of the Twenty-Four Parganas was fixed at 87.5 rupees per I00 maunds, but the lowest rate, which was 56.25 rupees in the I8Ios, increased to 75 rupees in the $1820 .^{52}$ Those measures, however, led to a general increase in costs for these agencies.

Difficulties in procuring fuel and a rise in its price began to affect distributions of advance money. The problem was most strongly felt in Bhulua due to its geographical location. According to J. Irwin, the salt agent of Bhulua and Chittagong, because one production area, Sandwip Island, produced no fuel it had to be supplied from the vast alluvia of its southern and eastern shore. ${ }^{33}$ The numerous shoals in the sea that became dry at low tide made it laborious and sometimes dangerous for the boats, laden with fuel, to reach the shore. In the season of I8I0-i 8 I I alone, at least seventeen fuel boats were lost in the surf.

The malangis on Hatia Island had formerly procured sufficient fuels from the "Neeluky Jungle" on the island, but the island's large tracts of fuel land were devastated by the encroachment of the Meghna, by constant soil erosion, and by the expansion in cultivation of other crops. The malangis on the island therefore had to depend on the southern extremity of Dakshin Shahbazpur Island for fuel, and the labour and transport costs of doing so weighed heavily on them. The Jagdia division too at the mouth of the Little Feni faced difficulties in the conveyance of fuel by boat because of the alluvial choking of the river. The agent's need to supply additional fuel explains the high rate of aurang charges of that agency.

Tamluk too faced difficulties in collecting fuel. Straw was sold at between 0.57 and 0.67 rupees per kahan during the period I 800 to I 807 , but the rate rose to as high as 2 rupees per kahan in $\mathrm{I} 8 \mathrm{I} 8 .{ }^{54}$ The agent saw the increase in straw price as incidental, but the growth of the straw

50. BRP-Salt, P/98/28, 2 I.8.1 800 , no. I; /P/100/47, $25 \cdot 3.1822$, no. 7 .

5. BRP-Salt, $\mathrm{P} / \mathrm{I00} / 47,25 \cdot 3.1822$, no. 7 .

52. Letters from the Several Agents, BT-Salt, vol. 86, 21.9. I 8 I 3; BRP-Salt, P/I or/22, 26.1.I 827, nos 9-2I; P/IOI/49, I4.4. I 829, nos I I-24.

53. Extract from the Agent's letter dated i 8 August i 8 I2, BT-Salt, vol. 86, 21.9.I8 8 3.

54. BRC-Salt, P/I00/22, 2.I0.I8I8, no. 6. The kahan was a measure of grain or straw. 
market in Calcutta gradually affected the price of it in surrounding areas. ${ }^{55}$ Straw was used to thatch houses and as a domestic fuel by mixing it with cow dung. The fact that the smoke generated by the burning of dung cakes was one of the major causes of air pollution in early nineteenth-century Calcutta suggests a growth in straw consumption there. ${ }^{56}$ It is highly likely that the growth of the market gave landowners, merchants, and peasants a strong incentive to sell the commodity on the open market. Under such circumstances, the malangis lost their customary right to collect paddy straw and had to buy more straw when they had no alternative. Moreover, it can be suggested that the growth of the silk industry, another major fuel-consuming industry in Bengal in the neighbourhood of the salt agency, increased competition for fuel.

The Twenty-Four Parganas, Jessore, and Bhulua agencies, which had comparable prime costs, bore higher costs in their salt production. When comparing the two periods in Figure 5, we can observe a significant increase in the khalari rent. Because of the particular geography of agencies in the Sundarbans area, saltpan sites there were vulnerable and it became necessary to lease ground for saltpans from landowners to maintain production levels.

\section{Employment opportunities and bargaining power of the malangis}

The Company tried to prevent not only production failures but also overproduction, as a large part of any surplus salt would enter the market illegally and reduce the price of legitimate supply. To control the total supply of salt, the Company kept the amount of Bengal salt below a certain level by reducing its production. Accordingly, each salt agent was responsible for keeping his agency's production level well below its actual capacity.

Constant cutbacks in production therefore reduced the income of malangis and undermined their trust in working under the Company monopoly. That provided a strong impetus to make extra salt illegally, by which salt makers could recoup losses caused by production cutbacks. Such illicit salt production was attractive, since the rate offered by smugglers was much higher than the rate of advances made by the Company, which was between 0.5 and 0.875 rupees per maund. For instance, the zamindars in Hijili, who smuggled to the interior, purchased salt from the malangis at a per maund rate of between I.4I and 2.56 rupees. ${ }^{57}$

55. BRP-Salt, $\mathrm{P} / \mathrm{IOI} / 24,3.4 .1827$, no. 24 .

56. M.R. Anderson, "The Conquest of Smoke: Legislation and Pollution in Colonial Calcutta", in David Arnold and Ramachandra Guha (eds), Nature, Culture, Imperialism: Essays on the Environmental History of South Asia (New Delhi [etc.], 1995), pp. 293-355, 297-298.

57. BRC-Salt, $\mathrm{P} / \mathrm{100} / 32$, 21.4.1820, no. 3. The zamindars employed peasants to purchase salt from the malangis and received it as their rents. 
To tackle the problem of illicit production, salt agents tried to use a surveillance system, composed of networks of native officers and informers known as goindas, to limit illegal activities by the malangis. More importantly, they had to look after the welfare of the malangis to prevent them from seeking other employment with better wages. In the I 8 I I-I 8 I 2 season, the Company decided to buy up surplus quantities of salt from the malangis to prevent it from flowing into the market illicitly, and the leap in production shown in Figure 3 was the direct consequence of that plan. The Company was satisfied with the result of its measure, stating that

$[\ldots]$ a large increase in [the] quantity of salt delivered by the manufacturers at the Company's Golahs [warehouses] and a consequent diminution in the quantity formerly smuggled by them from the aurangs [manufacturing divisions], it also had the effect of affording general satisfaction to the Molunghees [malangis] and operated as a check to smuggling in general throughout the country. ${ }^{58}$

In the season of I8I2-I8I3 too, the Company purchased surplus salt in expectation of an abundant production season. After that point, many agencies employed such purchase strategies. As the Board of Customs, Salt and Opium stated in I 822, the prevention of illicit traffic in the salt districts "can only be accomplished by granting to the Molunghees [malangis] an enhanced price for the salt which they may deliver in excess of their respective taidads [contracted quantities]". 59

However, the purchase of surplus salt was costly. Such purchases were intended to be only temporary, stopgap measures, but, as Figures 4 and 5 suggest, the practice became extremely difficult for the Company to eliminate once the malangis became used to higher prices. Unlike other agents, the salt agent of Hijili was unwilling to take the measure, judging it too expensive because Hijili could probably manufacture twice as much as the annual quota of production. ${ }^{6}$ Instead, the level of production was raised from 800,000 maunds to about $\mathrm{I}, 100,000$ maunds in the late I 8 IOS to increase the regular income of the malangis and prevent them from producing salt illegally. In addition, the successive agents of Hijili distributed rewards in kind to the most deserving and industrious malangis who reached a certain level of deliveries. Rewards consisted of pieces of broadcloth, various other types of cloth, red woollen lascars' caps, and small looking glasses. That unique reward system can be explained by the fact that employment opportunities for people in the district were limited to agriculture, and salt manufacture at John Palmer's estate on Sagar Island. ${ }^{61}$

58. Letter to the Governor General in Council, BT-Salt, vol. 86, 2 I.9.18 13 .

59. BRP-Salt, $\mathrm{P} / 100 / 47$, I9.3.1822, no. 16.

60. BRP-Salt, P/I0I/56, 6.II.1829, no. 7 .

61. Bodleian Library, Palmer Papers (MS English Letters, c.I05), Letter from John Palmer to J.

Reed (29.I 2.I 826), pp. I7-I8; Letter from John Palmer to J. Reed (26.I.I826), pp. I04-I06; 
In contrast to circumstances at Hijili, there was growing competition among different industries for the workforce in and around the salt agencies of Tamluk particularly, and in the Twenty-Four Parganas and Jessore. In Tamluk, the number of silk factories increased from 3 in I 803 to 37 in I 8 I $8,{ }^{62}$ as wages for silk factory labourers rose from 2.69 rupees per month in 1803 to 3.19 rupees in 1818 . That was a much higher wage than that of normal labourers, which ranged from 1.75 to 2.125 rupees in I 8 I 8 , and more locals seem to have been attracted to silk factories by it; the number of locals employed increased from 825 out of I,78 I in I 803 to 2,979 out of 3,104 in 18I8. In the Twenty-Four Parganas and Jessore agencies, the malangis sought employment in the indigo and sugar cane cultivation sectors. ${ }^{6}{ }^{3}$ The above observations suggest that the malangis were in a strong bargaining position vis-à-vis the Company, largely owing to the existence of smuggling fostered by the Company's high price strategy and because of labour scarcity in and around the salt agencies.

In other industries too, workers seemed to have enjoyed strong bargaining power with the Company. The opium industry in Bihar, which was also under Company monopoly, faced competition from the cultivation of other crops such as potatoes, and the illicit siphoning off of the workforce into other commercial pursuits. ${ }^{64}$ Similarly to what was done in the salt monopoly, the rate of advances to opium growers was, therefore, increased in I823. Even though they too received advances, the weavers employed by the Company were able also to sell their products clandestinely to other buyers, such as private traders of various nationalities. As Shubhra Chakrabarti puts it, "the English Company never could establish a total monopoly in the buyers' market". ${ }^{65}$ Producers of cash crops, excluding those of indigo and opium, sold their produce in open markets. ${ }^{66}$ Even indigo cultivators "looked better clothed and better conditioned than their neighbours" in the late I 820 , as Rammohan Roy observed. ${ }^{67}$

Letter from Ragoo Ram to J. Reed (7.3.1827), pp. 208-2 I0. The malangis were usually brought from Hijili to John Palmer's estate through a sardar [recruiter] from Khajuri.

62. BRC-Salt, $\mathrm{P} / 100 / 22$, 2.10.1818, no. 6.

63. Narendra Krishna Sinha, "Introduction", in idem (ed.), Midnapore Salt Papers: Hijili and Tamluk, I78I-I807 (Calcutta, I954), pp. I-24, 9.

64. Benoy Chowdhury, Growth of Commercial Agriculture in Bengal, 1757-I900 (Calcutta, I964), I, pp. $27-36$.

65. Shubhra Chakrabarti, "Collaboration and Resistance: Bengal Merchants and the English East India Company, I757-I833”, Studies in History, Io (1994), pp. I05-I 29, I I7-I 24.

66. S. Bhattacharya and B. Chaudhuri, "Regional Economy: Eastern India", in Dharma Kumar (ed.), The Cambridge Economic History of India, 2 vols (Cambridge, 1982-1983), II, pp. 270-332, 324-329.

67. Sugata Bose, Peasant Labour and Colonial Capital: Rural Bengal since 1770 (Cambridge, I993), pp. 47-48. 
These observations do not necessarily mean that the workers of various industries and those cultivating cash crops were well off. It is more likely that high revenue demand during the period meant that workers had to have multiple income sources to increase their earnings. As Sugata Bose points out, the production of cash crops such as indigo "not only promised a larger income but came with cash advances which could be used to pay the rent" ${ }^{68}$ And an individual's relationship with other members of the community, such as landowners, moneylenders, and peasants, certainly influenced how much he or she earned. In the i 830 , however, the conditions of indigo cultivators and weavers deteriorated. ${ }^{69}$ So, consequently, did those of the malangis, as the next section shows.

\section{THE EMERGENCE OF THE FUEL MARKET AND ITS IMPACT ON THE SALT INDUSTRY}

\section{Growing demand for coal}

The ever growing demand for safer, cheaper, and faster water transport for conveying goods, passengers, troops, and treasure between Calcutta and the upper provinces hastened the Company in establishing a stable river navigation. Lower Bengal had been well connected by water to north India and Assam, but although sophisticated the indigenous water communications were no longer sufficient for the growing demand in terms of volume as well as speed. According to J.H. Johnston, Controller of Government Steam Vessels, "the demand for water carriage frequently exceeds the available tonnage - it is always difficult to obtain boats for the service of the Government, and in cases of emergency they can only be procured by compulsion" ${ }^{\circ}$ In I 830, Johnston estimated that about 60,000 boats with a total capacity of 320,000 tons were employed in Bengal, among which more than 25,000 tons had been annually engaged for the service of government. However, "the quantity of goods actually embarked had not perhaps exceeded in each year seven or eight thousand" ${ }^{\text {I }}$ This was because the conveyance of goods needed to be accompanied by a fleet of boats with armed guards.

According to Cyril S. Fox, who served as the superintendent of the geological survey of India, evidence of burnt debris and outcrop fires in the Damodar Valley coalfields in Western Bengal suggests that "coal had been known in India from time immemorial, [...] yet when we turn to the

68. Ibid., p. 47 .

69. Ibid., pp. 47-48; B.R. Tomlinson, "Bengal Textiles, British Industrialisation, and the Company Raj: Muslins, Mules and Remittances, 1770-1 820”, Bulletin of Asia-Pacific Studies, 10 (2000), pp. 197-214, 209.

70. J.H. Johnston, Précis of Reports, Opinions, and Observations on the Navigation of the Rivers of India, by Steam Vessels (London, I831), p. 29.

7I. Ibid. 
literature and language of the country we find no mention of coal - there is no folk-lore, no legend, no story of any kind relating to these mysterious fires" ${ }^{72} \mathrm{He}$ further concluded that "it appears certain at all events that coal was not mined nor traded in by the people until John Sumner and Suetonius Grant Heatly discovered it in Bengal in 1774 and applied to Warren Hastings for permission to work coal mines". ${ }^{73}$ Commercial coal mining started in I8 Is when the first shaft mine was open at Raniganj in the Burdwan Coalfield. ${ }^{74}$ After the successful experimental voyage of the Hugli steamer on the Ganges in I828, the demand for coal rapidly increased and the Company emerged as the largest consumer of coal. The demand for bunker coal therefore created a market for coal in India for the first time in history.

After the Hugli, the Company launched 4 more river steamboats by I $840,{ }^{75}$ and the number had increased to Io by I 849 . In addition, it owned I9 seagoing steamships, and private companies had i 5 . Other consumers of coal were flour mills, foundries, and other powered factories in the Haora area near Calcutta. ${ }^{76}$ The demand for coal stimulated the development of the coal-mining industry in eastern India where the largest coalfield was situated in Burdwan. The annual production of Burdwan coal was $1,000,000$ maunds in the late 1830 , a figure which had increased to $2,500,000$ maunds by I $846 .{ }^{77} \mathrm{New}$ coalfields in Palamau, Sylhet, Assam, Cuttack (Orissa), and other places on the fringes of eastern India were investigated and developed at the same time. ${ }^{78}$

To achieve stable and regular steam navigation, it was inevitable that the Company would need to secure a consistent source of coal for its steamboats. The Company therefore introduced a contract system, in which contractors were expected to procure coal and convey it to the Company's coal depots along the main river routes between Calcutta and Allahabad, as well as between Calcutta and Assam (see Figure I). The Company's contract system, however, did not work well and many cases were reported of broken contracts. Particularly at the north Indian depots of Allahabad, Mirzapur, and Benares, firewood was frequently supplied instead of coal. The long

72. Cyril S. Fox, Coal in India: I (The Natural History of Indian Coal), Memoirs of the Geological Survey of India, LVII (Calcutta, 193I), p. 2.

73. Ibid.

74. About the earlier development of the Burdwan Coalfield, see Blair B. Kling, Partner in Empire: Dwarkanath Tagore and the Age of Enterprise in Eastern India (Calcutta, I98 I), pp. 94-I 2 I.

75. Ibid., p. 99. For the details of steamboats, see Henry T. Bernstein, Steamboats on the Ganges: An Exploration in the History of India's Modernization through Science and Technology (Hyderabad, i 960).

76. Kling, Partner in Empire, p. 98.

77. Ibid., p. Iо5.

78. IOR, Marine Department, Reports of Committee for Investigating the Coal Resources of India for I $84 \mathrm{I} \& \mathrm{I} 842, \mathrm{~L} / \mathrm{MAR} / \mathrm{C} / 604$. 
Table $2 \mathrm{~A}$. The price of firewood at various places in eastern India, I $836-I 840$.

\begin{tabular}{llrl}
\hline Places & \multicolumn{2}{c}{ (Company's rupees per 300 maunds)* } \\
\cline { 2 - 4 } & \multicolumn{1}{c}{ Month and Year } & Prices & Remarks \\
\hline Mirzapur Allahabad & Late 1836-early 1837 & 156.0 & \\
Allahabad & August 1839 & 110.7 & \\
City of Benares & February 1839 & 76.5 & \\
City of Benares & May 1839 & 77.4 & \\
City of Benares & July 1839 & 76.5 & \\
Ghazipur & May 1839 & 65.4 & Contract \\
Dinapur & August 1838 & 80.1 & Contract \\
Monghyr & August 1838 & 80.1 & Contract \\
Khulna & August 1838 & 80.1 & \\
Boalia & October 1840 & $30-33$ & \\
Boalia & November 1840 & 54.3 & \\
Kumarkhali & November 1840 & 60.0 & \\
\hline
\end{tabular}

distance from Calcutta to those depots made it difficult to transport coal in abundance and on time. In September and October i 836, the master of the Lord William Bentinck was forced to purchase coal at Monghyr and Dinapur because there was no coal owing to the failure to deliver by the contractor. ${ }^{79}$

In such places, firewood seems to have been readily available from local suppliers, ${ }^{80}$ although the price was extremely high. Tables $2 \mathrm{~A}$ and $2 \mathrm{~B}$, compare firewood and coal prices in the late 1830 s. Clearly, the price of firewood was much higher than that of coal, even though the price of Burdwan coal was as high as that of imported English coal. ${ }^{8 \mathrm{I}}$ The distance from Calcutta determined the price of coal at each depot. In the case of firewood, local availability seems to have influenced prices. Higher prices in Allahabad and other cities in north India no doubt resulted from the fact that the area along the Ganges had already suffered from very extensive deforestation, so that wood had to be brought from distant places. ${ }^{82}$

In Lower Bengal by contrast, the trade in wood for fuel was extremely limited and the Company's records of the procurement of firewood for

79. Bengal Steam Proceedings [hereafter, BSP], P/173/ı6, го.10.1836, nos 5, 8.

80. For instance, in order to make good a deficiency in coal at the Dinapur Depot, Jaggarnath Doss, a coal contractor, purchased I,I35 maunds of firewood from Byjun Bhuggut, a local merchant, through the agency of Toraub Khan, the Company's coal agent on the spot (BSP, P/ I73/18, 28.9.1837, no. I4).

8I. The main reason for the high price of Burdwan coal was the cost of transport via the Damodar to Calcutta and the difficulty in chartering sufficient numbers of boats and boatmen. The dominance of Carr, Tagore and Co. in the coal trade in Calcutta was also a factor. See Kling, Partner in Empire, p. 98.

82. Bernstein, Steamboats, p. I I I. 
Table $2 \mathrm{~B}$. The price of Burdwan coal at various coal depots in eastern India, $I 836-1842$.

\begin{tabular}{llcl}
\hline Coal depots & \multicolumn{3}{c}{ (Company's rupees per 100 maunds) } \\
\cline { 2 - 4 } & \multicolumn{1}{c}{ Month and Year } & Prices & Remarks \\
\hline Allahabad & October 1836-February 1837 & 109.8 & Contract \\
Mirzapur & October 1836-February 1837 & 86.7 & Contract \\
Ghazipur & October 1836-February 1837 & 80 & Contract \\
Dinapur & March-July 1838 & 80 & Contract \\
Monghyr & March-July 1838 & 74 & Contract \\
Colgong & March-July 1838 & 70 & Contract \\
Sarda & March-July 1838 & 70 & Contract \\
Rajmahal & March-July 1838 & 67 & Contract \\
Kumarkhali & March-July 1838 & 64 & Contract \\
Burhampur & March-July 1838 & 56 & Contract \\
Katwa & March-July 1838 & 55.5 & Contract \\
Kalna & March-July 1838 & 54 & Contract \\
Khulna & March-July 1838 & 54 & Contract \\
Calcutta & June 1839 & 45 & Contract \\
Calcutta & Early 1842 & 50 & \\
Calcutta & March-April 1842 & $75-81$ & \\
\hline
\end{tabular}

steamers provide a picture of the state of the firewood market there. When coal contractors failed to supply depots with coal or alternatively wood, the Controller of Government Steam Vessels had to act to obtain firewood for steamers from district collectors and magistrates. In June I 839, W. Swarman of the Dhaka Commissariat Office managed to obtain firewood for the Jamalpur coal depot from merchants who had stored it for the consumption of the troops. He stressed, however, that for future orders he would need advance notice because firewood was brought from "the place of growth". ${ }_{3}$ That meant there was no ready market for firewood in the vicinity of Jamalpur. Similarly, W.J. Allen, Joint Magistrate of Pabna District Criminal Court, claimed that it was impossible to procure the wood required for steamers, and in Pabna District firewood was consumed only in the Company's Kumarkhali silk filatures, it being obtained from the Sundarbans. ${ }^{84}$ In November I 840 , W.M. Dirom, the Collector of the same Pabna District, did manage to find wood suppliers to feed the coal depots at Boalia, Kumarkhali, and Khulna, although since the price was much higher than the highest price of coal the Controller had to decline the offer. ${ }^{85}$

83. BSP, $\mathrm{P} / \mathrm{I} 73 / 25$, I0.6.1 839 , no. 6.

84. BSP, P/I73/3 I, I6.I I.I 840 , no. II.

85. BSP, P/I73/3I, 9.II.1840, no. 26. 
The relative cheapness of firewood in Boalia and Kumarkhali (see Table 2A) can be explained by their easier access to the Sundarbans, where the Company procured wood for its filatures. In the Sundarbans area, there was a brisk trade in wood as building material. In particular, Nalchiti was the major wood market in eastern Bengal, dealing in wood from the Sundarbans and supplying chiefly to Narayanganj and Calcutta. ${ }^{86}$ It can be said that the existence of a buoyant timber trade began to facilitate the Company's procurement of wood as fuel.

\section{Fuel crisis and the decline of the salt industry}

There were several kinds of fuel-consuming industry in eastern India. Although a large amount of fuel was consumed, indigenous fuel markets developed on only a limited scale. Fuels were obtained locally through both non-market and market transactions, as in the case of the salt industry, which depended largely on straw and grass. In the indigenous silk industry in Birbhum District, cow dung was used for cocoon boiling in earthenware pans. ${ }^{87}$ In the vicinity of Dhaka, people depended on brushwood, reeds, and other plant stalks for fuel. ${ }^{88}$ A French army officer witnessed on the shore near Khajuri at the mouth of the Hugli "dry wood, consisting of branches of dead trees", which was to be sold in Calcutta. ${ }^{89}$ That officer's observations suggest that commercial logging to make firewood had been limited, largely because other biomass fuels were easily available. Thus, local vegetation influenced the choice of fuel, and industries seem to have adapted themselves to the use of local fuels.

As the previous section shows, the production of Bengal salt became costly in the I 820 s, and accordingly salt revenues began to decline in the late 1820 s and early i 830 s..$^{90}$ To save the monopoly as one of the most important sources of revenue in the face of the pressure to open the market to British industrial capital, the Company tried to reduce the cost

86. Bangladesh National Archives, Letter from R. Hunter, the Collector of Zillah Backergunge, on 27 June I8 18, Barisal Records, letters issued, vol. 226.

87. Ranjan Kumar Gupta, "Birbhum Silk Industry: A Study of its Growth to Decline", The Indian Economic and Social History Review, 17 (1980), pp. 2 I I-226, 2 I 3 . In the sugar industry in Gorakhpur in North India, various kinds of fuel materials were used: firewood imported from Nepal, bagasse, dried plant stalks, and shrub wood. See Shahid Amin, Sugarcane and Sugar in Gorakhpur: An Enquiry into Peasant Production for Capitalist Enterprise in Colonial India (Delhi, 1984), p. 82.

88. BSP, P/173/25, 10.6.1 839 , no. 6.

89. P. Thankappan Nair, Calcutta in the I8th Century: Impressions of Travellers (Calcutta, 1984), p. 217.

90. The average net revenue between the years $1822-1823$ and I $827-1828$ was $£_{1,342,210}$

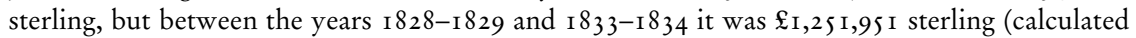
from Appendix no. 77 to the Report from the Select Committee on Salt, British India, BPP, vol. 17, 1836$)$. 
of production, and the reward system of Hijili was one of the targets for abolition. Although J. Donnithorn, the salt agent of Hijili, expressed anxiety that its abolition "will cause a vast number of them [malangis] to abandon altogether the occupation", ${ }^{11}$ it was indeed abolished in I829. From the late i 820 s, the abolition of the costly agencies themselves began to be discussed. However, since the Company depended heavily for large revenues on the high price of Bengal boiled salt, which was preferred by consumers, there was little incentive to abandon the Bengal method of production altogether or to search for alternative fuels. The boiling of brine using high-calorie fuels would have changed the quality of salt, and that would have met with strong opposition in the market.

When the abolition of the Bhulua agency was discussed in 1830 , the Company insisted that the deficiency had to be made up for by Hijili, Tamluk, or Cuttack (Orissa) boiled salt, not by solar salt imported from south India. ${ }^{92}$ Moreover, energy conversion to higher calorific materials such as wood and coal was financially unrealistic for the Company when salt revenues had been on the decline. The fuel market had already been tight, and a switch of fuels would require large investment in new skills, and equipment such as tougher boiling pans to withstand higher temperatures.

In 1836 the Company abandoned its high-price policy and introduced several measures to reduce the price of salt, since the widespread existence of problems caused by illicit production was one of the major reasons for rising costs. Salt began to be sold at a fixed price and the market was opened to private imports on which excise duties could be levied. The Company was able to break through its difficult situation and so saved its monopoly.

All the same, the new system did not solve the fuel problem. In Tamluk, in the 1830 s, the industry seems to have depended ever more on wood whenever it failed to procure sufficient grass and straw. According to the salt agent's report in 1834 , utilizing branches of trees in the small jungles on the Company's embankments and procuring firewood from Sagar Island could solve the deficiency in fuel. ${ }^{93}$ Firewood, which was probably brushwood or small branches of trees, was also brought to Tamluk from the jungle in the interior. ${ }^{94}$ The increasing difficulties in procuring fuel made the Tamluk agency look for alternatives. In the meantime, land cultivation and reclamation of the Sundarbans began on a large scale, and a large tract of wasteland was brought under cultivation. ${ }^{95}$

91. BRP-Salt, P/IOI/56, 6.I I.I829, no. 7. He estimated that about one-quarter of the workers would seek employment in other districts and economic sectors.

92. BRP-Salt, $\mathrm{P} / \mathrm{I} / \mathrm{I} / 54$, I 8.8.1 829 , no. 63.

93. BRP-Salt, $\mathrm{P} / \mathrm{I}_{4} / 84$, 7.1.1834, no. I7.

94. Ibid.

95. Iqbal, "Ecology, Economy and Society", pp. 6, i6, 35-44. 
The fuel problem became more serious in the early i 840 s. The tight supply and demand situation for coal became tighter still because of the outbreak of the Opium War in late 1839 and due to severe floods in Burdwan in 1840 . The price of the best Burdwan coal in Calcutta before the war was 0.45 rupees per maund, but this surged to $0.8 \mathrm{I}$ rupees in I 842 (see Table $2 \mathrm{~B}$ ). The rise in coal prices in the early $\mathrm{i} 840$ s seems to have affected the price of firewood, because the shortage of coal, due to a great rise in demand from river steamers, increased demand for wood as an alternative fuel, helping to make it a commodity. For instance, the price of firewood at Boalia increased 70 per cent in just a month in the late 1840 S (see Table 2A). The straw price too rose rapidly in Tamluk, from I.25 rupees per kahan in December 1839 to 2 rupees in $1842 .{ }^{96}$ As the price of coal returned to normal, the price of straw went down also to I.5 rupees per kahan in December 1845 and $1847 .{ }^{97}$ Such price information is limited, but similar fluctuations in various fuel prices suggest the emergence of an integrated fuel market.

Although recovery from it in the early i 840 os was quick, the fuel crisis had an enormous impact on the salt industry. The Bhulua agency was abolished in 1840 , and the costly separate operations in the Twenty-Four Parganas and Jessore agencies were also closed down, resulting in the integration of the management of the two agencies. In the remaining salt agencies of Hijili, Tamluk, and Chittagong, the Company secured fuels and at the same time saved expense by giving up distant grasslands and concentrating them close to the manufacturing sites. In so doing, the Company not only facilitated the malangis' fuel gathering but also converted distant grasslands into agricultural cultivation, thereby creating a new revenue stream from leases on those lands. ${ }^{9^{8}}$ In consequence, wood began to be more extensively used in salt manufacture. Even so, lack of fuel frequently halted production. ${ }^{99}$ The northern divisions in the Chittagong agency occasionally faced high prices or a severe scarcity of firewood, ${ }^{\mathrm{I} O}$ and of course when firewood prices were high the malangis suffered a great loss because the cost of fuel made up about 40 per cent of their total expenses. ${ }^{\text {IOI }}$

In the 184 os production of Bengal salt decreased by half, because of the closure of Bhulua, Jessore, and eventually the Twenty-Four Parganas, but

96. BRP-Salt, $\mathrm{P} /$ 106/9, I 1.2.1840, no. 10; $\mathrm{P} / 106 / 38$, 9.1.1843, no. I7.

97. BRP-Salt, $\mathrm{P} / \mathrm{ro6} / 65$, 2.I.I 846 , no. 59; P/109/28, 6.1.I848, no. I4.

98. Note on the Manufacture of Salt in the Tamluk Agency, Appendix B, BPP, vol. 26, I 856 , pp.

443-444.

99. BRP-Salt, $\mathrm{P} / 106 / 65,2.2 .1846$, no. 36.

I00. BRP-Salt, $\mathrm{P} / \mathrm{II}$ i $/ 24,25.2 .1857$, nos 6-7.

ıог. Note on Manufacture, Storage, Sale and Delivery of Salt in the Chittagong Agency, Appendix C, no. 2, BPP, vol. 26, I856, p. 478. 
the production of Bengal salt had already been in decline before the arrival of large quantities of Cheshire salt in the i 850 s. Further research is needed on the fate of former malangis in the I 840 s, but it is likely that the growing demand for labour in land reclamation in the Sundarbans absorbed them. However, by the mid-I830s western and central Bengal had become heavily populated, reaching densities of more than 700 per square mile, and as it did so the area gradually became malarial in the I 840 S. $^{102}$ Such increasing demographic pressure and unhealthy environments would have aggravated the working conditions of former malangis as well as of agricultural and industrial workers in general.

\section{CONCLUSION}

The salt industry in Bengal was able to produce a large amount of superior salt as well as considerable profits for the Company, thanks to the abundance of seawater and fuel. At the same time, the industry and its workers had to cope with the environmental difficulties surrounding them. They faced the constant danger of natural calamity, wild animals, and diseases. Occasional tidal floods, storms, and constant river encroachment were major causes of devastated saltpans and grasslands, which caused failures of production. The Company was responsible for giving the necessary assistance to the malangis whenever they faced difficulties in producing salt, since their level of productivity would affect salt revenues.

That did not ensure the well-being of the malangis, but at least circumstances were favourable for them. Severe competition from other employment opportunities also increased the malangis' income and bargaining power with the Company. As the Company at least liked to claim, the working conditions of the malangis were comparatively favourable, at least until the late i 820 .

However, working conditions began to deteriorate. Rising fuel costs contributed much to the weaker position of the malangis. In addition to the loss of grassland to environmental changes, reclamation of grassland for cultivation, which advanced particularly in the I830s, also reduced the availability of fuel for industrial activity. Expanding economic activities led to increased straw prices, as straw was used as a building material as well as fuel for domestic and industrial purposes. Further, the shortage of coal in the I83os encouraged commodification of other fuels, particularly wood. Straw prices also began to fluctuate in accordance with coal prices. Such new developments deprived the malangis of the customary right to procure straw and grass, and forced them to depend more on the market for fuel.

In the early nineteenth century, along with environmental changes, industrial and agricultural development as part of the globalization process

ı02. Klein, "Malaria and Mortality", p. I 56; Bose, Peasant Labour, pp. 22-24. 
led various industries to compete for energy resources. Because of the rise in production-related costs, the salt industry lost its competitiveness, long before the influx of Cheshire salt into its market. The fuel crisis in the early I 84 os, caused largely by the Opium War, came as a devastating blow to the salt industry and led to rapid shrinkage of the Company's monopoly. As Tomlinson points out, "once their exports became uncompetitive [...], the Company [...] moved on to other commodities and other producers, turning colonial Bengal into an exporter of primary products rather than manufactured goods" ${ }^{103}$ A large number of the salt workers lost one of their major sources of income, and it can be speculated that they were absorbed into agriculture and manual labour. 